УДК 378: $37.011 .3-051: 78+004$

\author{
Ашихміна Наталія Віталіївна \\ кандидат педагогічних наук, старший викладач кафедри диригентсько-хорової підготовки \\ Державний заклад «Південноукраїнський національний педагогічний університет \\ імені К. Д. Ушинського», м. Одеса, Україна \\ ORCID ID 0000-0001-8843-5217 \\ ashihmina_n-81@ukr.net
}

\title{
ВИКОРИСТАННЯ ЗАСОБІВ ІКТ ДЛЯ ФОРМУВАННЯ ФАХОВОЇ КОМПЕТЕНТНОСТІ МАЙБУТНІХ УЧИТЕЛІВ МУЗИЧНОГО МИСТЕЦТВА
}

\begin{abstract}
Анотація. У статті проаналізовано значення інформаційно-комунікаційних технологій для формування основних компонентів фахової компетентності здобувачів вищої освіти мистецьких факультетів педагогічних університетів. Визначено сутність фахової компетентності майбутніх учителів музичного мистецтва. На думку автора, означене поняття - інтегративна якість, що $€$ характеристикою набутих фахових знань, умінь, навичок, сформованих особистісних якостей під час фахової підготовки в межах мистецькопедагогічного вишу для якісного виконання професійної діяльності. Структура досліджуваного феномена складається 3 таких компонентів: мотиваційно-ціннісного, фахово-когнітивного, фахово-діяльнісного і рефлексивно-творчого. Зроблено висновок про те, що формування фахової компетентності майбутнього вчителя музичного мистецтва $\epsilon$ цілеспрямованим, безперервним i поетапним процесом особистісного прогресивного перетворення й удосконалення відповідно до вимог професійної музично-педагогічної діяльності. Автором запропоновані можливі організаційні дії для успішного формування досліджуваного феномена в межах мистецько-педагогічного вишу. Як імовірні ефективні способи формування основних компонентів фахової компетентності майбутніх учителів музичного мистецтва розглянуто певні засоби ІКТ. Зроблено такі припущення: формуванню мотиваційно-ціннісного компонента сприятиме залучення здобувачів вищої освіти до створення мультимедійних самопрезентацій і цифрових портфоліо в програмах PowerPoint та Authorware; формуванню фахово-когнітивного компонента - проєктування електронного підручника (або його фрагмента) у таких програмах: E-Book Maestro й Help and Manual EBook; формуванню фахово-діяльнісного компонента - використання нотних редакторів (Finale, Sibelius, Encore); формуванню рефлексивно-творчого компонента - застосування звукових редакторів (Sound Forge, Sternberg WaveLab) і музичних конструкторів (SunVox, NanoStudio, MadTracker, MuLab).
\end{abstract}

Ключові слова: фахова компетентність; компонентна структура фахової компетентності; інформаційно-комунікаційні технології; майбутній учитель музичного мистецтва.

\section{1. ВСТУП}

Постановка проблеми. Запити Нової української школи вимагають суттєвого перегляду завдань вищої професійної педагогічної освіти. Одним із найважливіших $є$ формування вчителя нового типу, котрий володіє високим науково-методичним потенціалом. Щоправда, сьогодні вже недостатньо ототожнювати професійне навчання майбутнього фахівця з накопиченням психолого-педагогічних і предметно-методичних знань та вмінь. Нова українська школа очікує не просто на професіонала, який добре знає методичні рекомендації та вміє ними користуватись, а на компетентного фахівця, здатного грамотно і швидко реагувати на мінливі умови професійної діяльності, адекватно оцінювати навчально-виховні ситуації, вирішувати безліч практичних завдань і водночас обов'язково вміло використовувати інформаційно-комунікаційні технології (далі - IКТ).

Відтак, актуальним є активне вкорінення в освітній процес педагогічних вишів 
інноваційних засобів навчання. Про необхідність такого впровадження йдеться в багатьох нормативно-правових документах, як-от: Національна стратегія розвитку освіти в Україні на період до 2021 року (2013), Закон України «Про вищу освіту» (2014), Закон України «Про наукову та науково-технічну діяльність» (2016), Закон України «Про освіту» (2017) тощо. Однак за даними останніх психолого-педагогічних досліджень, ІКТ використовують в освітньому процесі закладів вищої освіти без достатньо обгрунтованих теоретичних розробок, часто без необхідного педагогічного осмислення - i, як наслідок, не всі майбутні фахівці готові до здійснення професійної діяльності на новому, інформаційно-комунікаційному, рівні [1], [2], [3].

Сучасний етап розвитку системи вищої мистецької освіти також характеризується концептуальними трансформаціями, що вимагають зміни ставлення до звичних, традиційних поглядів на зміст, методи і форми формування фахової компетентності майбутніх учителів музичного мистецтва. Слід підкреслити, що фахова діяльність у ії ідеальному втіленні є простором індивідуальної творчості вчителя, у якій тонко поєднані класичні традиції мистецької педагогіки і музичного мистецтва з сучасними педагогічними ідеями та особистісними методичними досягненнями. Цей ідеал не втратив актуальності й сьогодні, однак набув сучасної характеристики. Адекватним у сучасних умовах стає такий вектор формування фахової компетентності майбутнього вчителя музичного мистецтва, який орієнтується на високі ідеали мистецтва i художньої освіти через органічний синтез культурно-історичного досвіду 3 інноваційністю, зокрема завдяки використанню IКТ.

Порівняно з традиційним навчанням музичного мистецтва ІКТ дають низку переваг: інтерактивних, дидактичних, інтегральних, психологічних, професійнопедагогічних, ергономічних, економічних тощо. Новітні технології значно розширюють межі формування фахової компетентності майбутніх учителів музичного мистецтва, сприяють урізноманітненню художньо-освітнього процесу, динамізують його, а відтак забезпечують зміну ролі здобувача вищої мистецької освіти: він з пасивного слухача стає активним учасником, готовим до компетентного виконання фахової діяльності.

Аналіз останніх досліджень і публікацій. Вивчення результатів науковометодичних розвідок і практичних рекомендацій учених свідчить про те, що проблему використання IКТ у підготовці майбутніх фахівців розглянуто під різним кутом. Означене питання в аспекті визначення загальнодидактичних принципів навчання досліджували Ю. Бабанський, І. Лернер, М. Скаткін та ін., в аспекті розробки теорії безперервної освіти - О. Новікова, М. Нечаєв та ін., 3 позицій вивчення особливостей підготовки педагогів різних профілів у галузі ІКТ - Л. Босова, О. Козлов, І. Роберт та ін. Педагоги, серед яких: В. Биков, І. Захарова, В. Кухаренко, Н. Морзе, О. Пєхота, С. Сисоєва, П. Стефаненко, С. Полат та ін., звернули увагу на той факт, що інтеграція в навчальному процесі сучасних освітніх технологій з ІКТ забезпечує ефективність усіх видів навчальної діяльності, виховує професіоналів з новим типом мислення відповідно до вимог інформаційного суспільства, а головне - сприяє формуванню в майбутніх фахівців професійної культури і фахової компетентності.

У педагогіці вивченню понять «компетенція», «компетентність», «професійна компетентність», «фахова компетентність» як провідних категорій компетентнісного підходу присвячено багато робіт зарубіжних учених, зокрема А. Вербицького, Е. Зеєра, I. Зимньої, Н. Кузьміної, Дж. Равена, Г. Селевка, В. Хутмахера та ін., і українських науковців: О. Гури, Я. Кодлюк, А. Комишана, В. Лугового, О. Овчарук, Н. Побірченко, К. Хударковського та ін.

У дослідженнях А. Бермуса, М. Бершадського, В. Болотова, М. Васильєвої, С. Вітвицької, Б. Ельконіна, С. Сисоєвої, Н. Тализіної та багатьох інших задекларовано, що в компетентного фахівця розвинене вільне мислення, сформовані надпредметні 
знання та вміння, які готують особистість до самостійного набуття інформації з різних джерел, зокрема з новітніх - електронних, і усвідомлення іiї важливості.

У галузі мистецької освіти окремі питання щодо формування професійної компетентності майбутніх фахівців у галузі мистецької освіти у своїх працях розглядали А. Болгарський, О. Горбенко, О. Гребенюк, С. Грозан, Ю. Калініна, Л. Лабінцева, О. Ляшенко, О. Кузнецова, М. Михаськова, Л. Пастушенко, О. Щолокова та багато ін. Означені педагоги вивчали такі проблеми: становлення професійнопедагогічної компетентності вчителя музики; залучення здобувачів мистецькопедагогічних вишів до процесу художньої самоосвіти в якості умови розвитку їх професійної компетентності; формування компетентності саморозвитку майбутніх фахівців у галузі мистецької освіти; формування професійної компетентності майбутніх учителів музики в процесі виконавської діяльності тощо.

Аналіз наукової літератури засвідчує, що проблема формування фахової компетентності майбутніх учителів музичного мистецтва через упровадження в художньо-освітній процес засобів ІКТ досі залишається не вирішеною. Серед українських учених, які нині намагаються вирішити питання про доцільність та специфіку застосування ІКТ під час музичного навчання здобувачів вищої педагогічної освіти, слід відзначити: Н. Попович [4] - досліджує особливості інтеграції ІКТ у систему професійної підготовки здобувачів мистецько-педагогічних вишів; В. Гаврілову і В. Федоришина [5] - пропонують теоретичні розвідки щодо формування професійної компетентності майбутніх фахівців у галузі музичного мистецтва засобами комп'ютерних технологій; I. Пащенко [6] - розглядає особливості впровадження IКТ у систему підготовки майбутніх учителів музичного мистецтва.

Огляд новітніх зарубіжних праць, у яких висвітлюються ймовірні шляхи впровадження IКТ у галузь музичного мистецтва, а також у систему підготовки майбутніх фахівців цієї галузі, свідчить про те, що заявлена проблема за кордоном $\epsilon$ більш резонансною, ніж в Україні. Так, білоруська дослідниця О. Шарабайко [7] вивчає зміст фахової підготовки майбутніх учителів музики в галузі ІКТ, а також сутність інформаційно-комунікаційної компетентності вчителя музики. Н. Неделюк і С. Поп [8] досліджують проблему інтеграції ІКТ з метою розвитку дистанційної підготовки викладачів музики. Учені надали результати впровадження спеціально розроблених освітніх заходів, проведених в Музичній академії імені Георге Діма (м. Клуж-Напока, Румунія), щодо адаптації вимог навчання музичного мистецтва до завдань педагогічної університетської підготовки. Іспанські вчені А. Муріло-Рібес, М. Ріано-Галан і Н. Бербел-Гомес [9], зробили висновок, що використання IКТ під час музичного навчання сприяе творчому розвитку i формуванню у студентів університету міжособистісних компетентностей. О. Кендл [10] розглядає питання мотивованого ставлення до музичного навчання завдяки гейміфікації освіти. Індонезійські дослідники Дж. Джулія, Т. Супріяді та П. Ісвара [11] аналізують шляхи розробки навчальних матеріалів із залученням IКТ для формування й удосконалення в студентів навичок комп'ютерної обробки музичного матеріалу. Австралійський учений Р. Крауфорд [12] розкриває потенціал IКТ у контексті змішаного навчання музичного мистецтва.

Отже, аналіз сучасного стану системи фахової підготовки майбутніх учителів музичного мистецтва в Україні демонструє існування суперечності між встановленими вимогами до виховання компетентного фахівця в галузі мистецької освіти й обмеженістю використання ІКТ у практиці фахової підготовки здобувачів вищої освіти.

Мета статті - визначити ймовірні ефективні засоби IКТ для формування основних компонентів фахової компетентності майбутніх учителів музичного мистецтва. 


\section{2. МЕТОДИ ДОСЛІДЖННЯ}

Пропоноване дослідження проведене з використанням методів аналізу, синтезу і класифікації науково-методичної літератури з метою визначення ключових понять дослідження та ймовірних ефективних засобів IКТ для формування основних компонентів фахової компетентності майбутніх учителів музичного мистецтва.

\section{3. РЕЗУЛЬТАТИ ДОСЛІДЖЕННЯ}

Нині спостерігаємо перехід професійної освіти від гностичного, так званого «знаннєвого», підходу до особистісно діяльнісного, що пов'язаний із пошуком шляхів гармонізації навчання через збалансовану соціально-особистісну орієнтацію освітнього процесу і повноцінне віддзеркалення в ньому всіх основних цінностей та елементів культури (науки, мистецтва, релігій, традицій народної педагогіки тощо), а також продуктивну співпрацю всіх учасників цього процесу й реалізацію основних функцій освіти (інформаційно-когнітивної, розвивальної, соціально-перетворюючої, культуротворчої, пошуково-перетворювальної тощо). Це означає, що ключовою метою сучасної вищої освіти стає формування в ії здобувачів здатності до активної фахової діяльності, яка, своєю чергою, слугує засобом їх особистісного розвитку, тобто йдеться про формування фахової компетентності.

Слід наголосити, що терміни «компетентність» i «компетенція» сьогодні використовують у науково-педагогічній літературі й нормативно-правових документах для опису якості фахової підготовки й часто ототожнюють, а тому використовують як синонімічні. Це свідчить про відсутність одностайності серед науковців щодо їх дефінування.

У Рамковій програмі оновлених ключових компетентностей для навчання протягом життя, схваленій Європейським Парламентом та Радою Європейського Союзу 17 січня 2018 р., компетентність визначено як комбінацію знань, навичок та ставлень, де: знання складаються з фактів і цифр, концепцій, ідей та теорій, які вже встановлені та підтримують розуміння певної сфери або предмета; навички визначаються як здатність та спроможність виконувати процеси та використовувати набуті знання для досягнення результатів; ставлення описують диспозиції сприйняття і налаштованості щодо ідей, людини або ситуації й спонукають до відповідних реакцій або дій [13].

У Законі України «Про освіту» задекларовано, що «компетентність - це «динамічна комбінація знань, умінь, навичок, способів мислення, поглядів, цінностей, інших особистих якостей, що визначає здатність особи успішно соціалізуватися, провадити професійну та/або подальшу навчальну діяльність» [14]. Визначення поняття «компетенція» в Законі відсутнє. Щоправда, воно використовується в цьому ж нормативно-правовому документі 3 позиції функціонального призначення, повноважень й обов'язків державних органів та органів місцевого самоврядування у сфері освіти.

А. Хуторський наголошує на неоднорідності понять «компетентність» i «компетенція». На думку вченого, компетенція - це сукупність якостей особистості, які $\epsilon$ взаємопов'язаними i заданими певними предметами, процесами тощо, а компетентність - результат оволодіння людиною відповідною компетенцією (або компетенціями) [15].

Умовиводи В. Калініна свідчать про те, що поняття «компетентність» характеризує і визначає рівень професіоналізму особистості. Воно є ширшим, ніж поняття «компетенція». Формування компетентності відбувається завдяки набуттю 
певних, необхідних для майбутнього фахівця компетенцій $[16$, с. 8]. М. Головань стверджує, що поняття «компетенція» - це те, що пов'язане зі змістом сфери діяльності особистості, а компетентність є характеристикою здатності людини якісно виконувати певну діяльність [17, с. 230].

Учені пропонують класифікувати компетенції через виокремлення: ключових компетенцій (загальні компетенції, необхідні для соціально продуктивної діяльності); базових (у певній професійній галузі); професійних (для виконання конкретної дії, вирішення конкретної проблеми або професійного завдання). Набуття професійних компетенцій $є$ дієвим чинником професійного розвитку особистості та, водночас, індикатором особливостей становлення фахівця, тобто формування його фахової компетентності.

Поняття «фах» у науковій літературі визначають як вид заняття, трудової діяльності, що вимагає певної підготовки і є основним засобом до існування; професія. Часто означений термін, як і слово «спеціальність», ставлять на один щабель із поняттям «вид діяльності», що увиразнює такі компоненти, як-от: «галузева професія», «окрема галузь професійної діяльності», «вид професійної діяльності», «професійна діяльність у межах окремої галузі», «окрема ділянка професійної діяльності», «професійна діяльність щодо чого-небудь» тощо [18].

Отже, фах і компетентність - два аспекти, що характеризують один феномен професійну діяльність, розуміння сутності якої допомагає в дослідженні проблеми формування фахової компетентності. Професійна діяльність - це складний продуктивний процес виконання особистістю певних дій у межах професії на основі набутих фахових знань, умінь і навичок, що вимагає певної підготовленості й освіти. Така характеристика професійної діяльності дає змогу умовно виділити два основних підходи до визначення фахової компетентності - особистісний і функціональний.

Особистісний підхід спрямовано на виявлення поведінкових характеристик компетентності; основна проблема - визначити, які особистісні риси $є$ передумовою успішності виконуваних дій. У цьому сенсі компетентність розуміють як основний поведінковий аспект або характеристику, що може проявлятися в ефективній i/aбо успішній дії та залежить від контексту дій, організованих факторів, цінностей середовища, а також параметрів фахової діяльності.

Із позиції функціонального підходу фахову компетентність характеризують як виконання діяльності на високому професійному рівні, що зумовлене наявністю в особистості грунтовних фахових знань й умілим їх використанням на практиці.

Вищеозначене дає підстави фаховою компетентністю майбутнього вчителя музичного мистецтва вважати інтегративну якість, що є характеристикою набутих фахових знань, умінь, навичок, сформованих особистісних якостей під час фахової підготовки в межах мистецько-педагогічного вишу для якісного виконання професійної діяльності.

Специфіку підготовки майбутніх фахівців у галузі мистецької освіти досліджувало багато педагогів у галузі мистецької освіти, зокрема такі: О. Андрейко, I. Гринчук, Н. Гузій, А. Козир, О. Отич, Г. Падалка, О. Ростовський, О. Рудницька, Н. Сегеда, О. Хижна, О. Хлєбнікова, Н. Цюлюпа та ін. У наукових розвідках цих дослідників зазначено, що мистецько-педагогічна підготовка $є$ складним процесом, спрямованим на набуття здобувачами вищої освіти комплексу фахових компетенцій. Під ключовими фаховими компетенціями в контексті нашого дослідження визначаємо такі, що використовують у всіх видах професійної діяльності вчителя музичного мистецтва. Це той комплекс знань, умінь, навичок, якостей, практичного досвіду, який слід опанувати здобувачу вищої освіти під час формування фахової компетентності для якісного виконання майбутньої професійної діяльності. 
Фахові компетенції містять не тільки когнітивну й операційно-технологічну складові, а й мотиваційну, соціально-поведінкову, а також результати навчання, систему ціннісних орієнтацій тощо.

Враховуючи вищеозначене, можна припустити, що компонентний склад фахової компетентності припускає наявність: мотиваційно-ціннісного компонента (наявність у майбутніх учителів музичного мистецтва прагнення до набуття фахових компетенцій у галузі музичної освіти, позитивної мотивації до фахового навчання, усвідомлення об'єктивної та суб'єктивної цінності фахової підготовки); фахово-когнітивного компонента (передбачає оволодіння особистістю системою фахових знань, осмислене сприйняття і розуміння цілей та завдань фахової підготовки); фахово-діяльнісного компонента (характеризується сукупністю фахових умінь і навичок здобувачів, а також здатністю до пошуку й визначення оптимальних прийомів фахово-пізнавальних, художньо-виконавських дій); рефлексивно-творчого компонента (віддзеркалює наявність здібностей до створення власних моделей фахового навчання, самонавчання, самомоніторингу, а також до рефлексії результатів фахової підготовки як основи проєктування траєкторії фахового саморозвитку).

Грунтуючись на вищеозначених результатах дослідження порушеної проблеми, пропонуємо наше визначення поняття «формування фахової компетентності майбутніх учителів музичного мистецтва». Це цілеспрямований, безперервний і поетапний процес особистісного прогресивного перетворення й удосконалення здобувачів вищої освіти відповідно до вимог професійної музично-педагогічної діяльності. Зробимо спробу запропонувати ймовірні організаційні дії щодо успішного здійснення цього процесу в межах мистецько-педагогічного вишу. Для цього розглянемо IКТ як одних 3 ефективних способів формування основних компонентів фахової компетентності майбутніх учителів музичного мистецтва.

Поняття «ІКТ» (від англ. Information and communications technology) часто вживають як синонім до інформаційних технологій (IT). Уперше його було вжито в 1997 році в доповіді Д. Стівенсона для уряду Великобританії, що посприяло створенню нового Національного навчального плану Великої Британії в 2000 році. Н. Філіппенко зауважує, що IKT - це більш загальний термін, який підкреслює інтеграцію телекомунікацій (телефонних ліній і бездротових з'єднань), комп'ютерів, програмного забезпечення, накопичувальних та аудіовізуальних систем, що дозволяють користувачам створювати, одержувати доступ, зберігати, передавати та змінювати інформацію. Дослідниця звертає увагу на той факт, що IKT містить IT, а також телекомунікації, медіатрансляції, усі види аудіо і відеообробки, передачі, мережеві функції управління та моніторингу [19, с. 23].

На думку О. Листопада, поняття «ІКТ» означає використання на основі комп'ютерів інформаційних і комунікаційних систем для обробки, передачі і зберігання даних та інформації. ІКТ містять відповідну законодавчу базу, інформаційні ресурси, кваліфікований персонал, що володіє механізмами, способами обробки інформаційних ресурсів, інфраструктуру 3 виробництва та експлуатації різних технічних, телекомунікаційних та програмних засобів [20].

Н. Попович вважає, що сучасне впровадження IКТ в освітній процес мистецькопедагогічного вишу зумовлене соціальними проблемами підвищення статусу викладача музичного мистецтва відповідно до здобутого ним освітнього ступеня або міри здатності й готовності виконувати професійні функції. Застосування інформаційних технологій у сфері мистецької освіти забезпечує якісно новий рівень набуття й узагальнення знань, умінь і навичок фахівців, їх використання в подальшій професійній і творчій діяльності [4]. 
IКТ можна вважати тими новими способами передачі знань, які відповідають новому змісту вищої мистецької освіти. Ці технології не тільки значно підвищують ефективність засвоєння художньо-освітнього матеріалу майбутніми фахівцями, стимулюють інтерес до професійної діяльності, дозволяють в інноваційній формі ставити перед здобувачами художньо-освітні та виконавсько-творчі завдання, допомагають нестандартно й творчо вирішувати їх, а також сприяють формуванню цифрової компетентності.

Сучасна зміна освітньої парадигми спричинила до того, що професійна діяльність учителя музичного мистецтва стає більш багатогранною, зокрема в ній з'являються нові функції, оскільки в процес музичного виховання нового покоління починають активно інтегруватися електронні засоби навчання - програмно-методичне забезпечення (носії інформації, інструменти навчальної діяльності), яке сприяє сучасному й ефективному опануванню учнями навчального матеріалу. Тому сьогодні перед мистецько-педагогічним вишем постає нове завдання оптимізації співвідношення між фаховою і цифровою компетентностями майбутніх учителів музичного мистецтва.

Рамкова програма ЄС щодо оновлених ключових компетентностей визначає цифрову компетентність як впевнене, критичне, відповідальне використання i взаємодію з цифровими технологіями для навчання, професійної діяльності (роботи) та участі в житті суспільства. Ця компетентність характеризується такими параметрами: цифровою та інформаційною грамотністю; сформованими навичками щодо комунікації, співпраці й створення цифрового контенту (зокрема програмування); набутими знаннями з основ кібербезпеки та усунення цифрових проблем [13].

Отже, оптимізації формуванню фахової та цифрової компетентностей майбутніх учителів музичного мистецтва сприятиме інтеграція в художньо-освітній процес IКТ. T. Зінська звертає увагу на те, що мистецька спрямованість будь-яких музичних дисциплін передбачає передовсім живе спілкування, а тому застосування навіть найсучасніших IКТ не зможе повністю реалізувати завдання щодо виховання професійного музиканта. Наприклад, віртуальний синтезатор 3 комп’ютерною клавіатурою не замінить «живий» музичний інструмент (акордеон чи фортепіано). Однак використання ІКТ як допоміжних, додаткових засобів значно розширює можливості освітнього процесу в аудиторній або позааудиторній діяльності, у самопідготовці та творчості [21, с. 457]. Розглянемо більш детально важливість використання IКТ під час формування кожного з вищеозначених компонентів фахової компетентності майбутніх учителів музичного мистецтва.

Формування мотиваційно-ціннісного компонента досліджуваного феномена зумовлене актуалізацією позитивного і ціннісного ставлення до процесу фахового самовдосконалення під час залучення здобувачів вищої освіти до визначення власного фахово-творчого потенціалу, цінності мистецької освіти й набуття фахових компетенцій. Можна припустити, що означеному сприятиме залучення майбутніх учителів музичного мистецтва до створення мультимедійних самопрезентацій i цифрових портфоліо.

Створення мультимедійних самопрезентацій і цифрового портфоліо, а також їх використання в освітньому процесі дозволить навчанню стати більш гнучким, підвищить мотивацію та інтерес здобувачів вищої освіти до вивчення фахових дисциплін, а також сприятиме формуванню інформаційно-комунікаційної компетенції.

Залучення майбутніх учителів музичного мистецтва до самостійного створення мультимедійних самопрезентацій буде спонукати до діагностування і презентації своїх фахово-творчих потенцій у професійній галузі. Такі самопрезентації є поєднанням тексту, графіки, відео і звукового ряду, а тому дозволять майбутнім фахівцям максимально розкрити їх художньо-освітні й творчі можливості, емоційність, 
продемонструвати фахову грамотність та ерудованість, змоделювати власний фаховий образ. Створення мультимедійної самопрезентації - це деталізована і багатоетапна робота. Тож, показуючи готовий продукт, майбутній учитель музичного мистецтва зможе продемонструвати знання, уміння i навички щодо формування концепції самопрезентації, створення іiі сценарію, вставки анімації, звукового оформлення, створення індивідуального дизайну самопрезентації тощо. Створення цифрового портфоліо, тобто власного фахового портрета, для здобувача вищої освіти-майбутнього вчителя музичного мистецтва $\epsilon$ педагогічно значущим, оскільки це додаткова форма вираження успішності, зростання його художньо-освітньої кар'єри. Програми, у яких здобувачі вищої освіти можуть створювати мультимедійні самопрезентації та цифрові портфоліо, інтуїтивно зрозумілі і прості у вивченні, наприклад: PowerPoint або Authorware.

Формування фахово-когнітивного компонента фахової компетентності майбутніх учителів музичного мистецтва пов'язане з розширенням у них музично-педагогічного тезаурусу, музично-стильових уявлень, обізнаності в галузі тощо. Розумне використання певних засобів ІКТ, серед яких комп'ютер, у музичному навчанні може сприяти більш повній реалізації основних музично-дидактичних принципів. По-перше, комп'ютер дозволяе істотно збільшити обсяг використовуваного в педагогічній роботі матеріалу за рахунок компактного і централізованого його розміщення в ПК. По-друге, темпи проходження цього матеріалу значно прискорюються, позаяк комп'ютер володіє багатими сервісними можливостями і надає користувачеві засоби для швидкого отримання інформації та оперативної іï обробки. Все це забезпечує збільшення теоретичного обсягу занять, а орієнтація комп'ютерного навчання на діяльнісний підхід дозволяє максимально активізувати самостійність i творчу ініціативу майбутніх фахівців завдяки використанню продуктивних способів діяльності на заняттях (створення музичного твору, імпровізація, моделювання тощо).

Створення здобувачами вищої освіти електронного підручника (або його фрагмента) з певної дисципліни, виконаного в одній з відповідних програм, наприклад, E-Book Maestro, Help and Manual E-Book, залучатиме майбутніх фахівців до організації за певною тематикою тексту з гіперпосиланнями, ілюстраціями, графіками, музикою і відео. Майбутні вчителі музичного мистецтва завдяки сформованим уявлення про електронні типові моделі реалізації електронного підручника і отриманим знанням та вмінням, необхідним для його розробки, самостійно зможуть презентувати готовий закінчений продукт, який можна використовувати в подальшій фаховій діяльності.

Формування фахово-діяльнісного компонента пов'язане 3 удосконаленням у здобувачів вищої освіти вмінь і навичок творчого трактування музичних творів, залученням до творчої діалогової взаємодії, оптимального вибору художньо-освітніх засобів для розкриття власного художньо-творчого та фахового потенціалу тощо. Реалізації означеного сприятиме використанню в художньо-освітньому процесі нотних peдакторів (Finale, Sibelius, Encore) - комп'ютерних програм для створення, обробки і форматування нотного тексту різної складності. Зокрема здобувач вищої освіти зможе продемонструвати рівень володіння програмами через створення в певному форматі партитури (наприклад, в діапазоні від фортепіанної п'єси або гітарних табулятур до симфонічної партитури). Крім того, у нотному редакторі $є$ можливість створити партитуру такого рівня складності, яку не зможе зіграти жоден віртуоз-музикант, Комп'ютер же з легкістю програє музичний твір різної фактури в будь-якому заданому темпі, тональності й оркестровому складі. Набуті вміння і навички роботи в нотних редакторах, зокрема на заняттях з музичної інформатики, майбутні вчителі музичного мистецтва можуть успішно використовувати під час вивчення таких дисциплін: «Гармонія з основами поліфонії», «Основи теорії музики і сольфеджіо», «Аранжування 
та імпровізація», «Хорове диригування», «Хорознавство», «Хоровий клас», «Методика музичного виховання», «Основний музичний інструмент», «Концертмейстерський клас», «Оркестровий клас (ансамбль)», а також під час оформлення наукових робіт, написання анотацій до музично-педагогічних колекцій i хорових творів, розробки авторських методичних посібників тощо.

Формування рефлексивно-творчого компонента фахової компетентності передбачає залучення здобувачів вищої освіти до оцінювання результатів творчої фахової самореалізації та самокорекції. Можна припустити, що реалізація означеного стане можливою завдяки залученню майбутніх фахівців до використання звукових редакторів (Sound Forge, Sternberg WaveLab), наприклад, для створення реміксів. Ремікс $\epsilon$ новою версією музичного твору, котра збудована шляхом зведення записаних доріжок і накладення на них різних звуків, ефектів, зміни темпу, тональності. Робота майбутніх учителів музичного мистецтва в різних звукових редакторах надасть можливості продемонструвати не тільки результати власної творчості, а й рівень сформованості умінь і навичок з редагування музики, розробки нових можливостей звучання, реставрації старих музичних записів тощо.

Також ефективним щодо формування рефлексивно-творчого компонента може стати використання такого типу програмного забезпечення, як музичні конструктори - SunVox, NanoStudio, MadTracker, MuLab (робота на їх основі не потребує MIDIклавіатури або синтезатора). Функціонально ці програми дуже прості. Вони $\epsilon$ багатодоріжковими студіями, за допомогою яких можна конструювати музику потрібного стилю. Такі конструктори дозволяють майбутнім фахівцям створювати не лише музичні фрази, а й цілі твори з окремих музичних елементів (семплів). Це програмне забезпечення добре «працюватиме» під час реалізації тих віртуальних проєктів, де система творчих завдань зорієнтована на активну роботу здобувачів вищої освіти. Наприклад, створення загального мікса із записаного кожним майбутнім фахівцем музичного фрагмента; створення індивідуальної конкурсної композиції на загальну тему через використання готових семплів із збереженням альянсу між готовими творами за стилістикою, тематикою і задумом; створення реміксу на основі класичного музичного твору тощо.

\section{4. ВИСНОВКИ ТА ПЕРСПЕКТИВИ ПОДАЛЬШИХ ДОСЛІДЖЕНЬ}

Отже, сучасні вимоги щодо підготовки майбутнього вчителя музичного мистецтва для роботи в Новій українській школі пов'язані із значним розширенням діапазону його діяльності і підвищенням рівня фахової компетентності. Це зумовлює оновлення традиційних форм музичного навчання, модернізацію освітньо-професійних програм, робочих програм фахових навчальних дисциплін, упровадження авторських методик, уведення нових додаткових спеціалізацій, профілізацію традиційних дисциплін тощо. У зв'язку з цим тенденція до використання інноваційних засобів навчання та ІКТ в освітньому процесі мистецько-педагогічних вишів сьогодні стає необхідністю, позаяк дозволяє значно оптимізувати формування в майбутніх учителів музичного мистецтва фахової компетентності.

Фахова компетентність майбутнього вчителя музичного мистецтва - інтегративна якість, що є характеристикою набутих фахових знань, умінь, навичок, сформованих особистісних якостей під час фахової підготовки в межах мистецько-педагогічного вишу для якісного виконання професійної діяльності. Структура досліджуваного феномена містить такі компоненти: мотиваційно-ціннісний, фахово-когнітивний, фахово-діяльнісний і рефлексивно-творчий. 
Формування фахової компетентності майбутнього вчителя музичного мистецтва цілеспрямований, безперервний і поетапний процес його особистісного прогресивного перетворення й удосконалення відповідно до вимог професійної музично-педагогічної діяльності. Зважаючи на актуальність і важливість використання засобів ІКТ для формування досліджуваного феномена, можемо припустити, що формуванню мотиваційно-ціннісного компонента фахової компетентності сприятиме залучення здобувачів вищої освіти до створення мультимедійних самопрезентацій і цифрових портфоліо; формуванню фахово-когнітивного компонента - проєктування електронного підручника; формуванню фахово-діяльнісного компонента використання нотних редакторів; формуванню рефлексивно-творчого компонента застосування звукових редакторів і музичних конструкторів.

Перспективними аспектами при подальшій розробці проблеми можуть стати: розробка методики впровадження інформаційно-комунікаційних технологій у процес виконавсько-інструментальної підготовки майбутніх учителів музичного мистецтва; визначення ефективних засобів ІКТ для формування диригентсько-хорової і вокальної культури здобувачів вищої мистецько-педагогічної освіти.

\section{СПИСОК ВИКОРИСТАНИХ ДЖЕРЕЛ}

[1] І. Юцевич, "Проблема готовності майбутніх учителів іноземних мов до використання інформаційних технологій у процесі фахової підготовки”, Вісник Чернігівського національного педагогічного університету, Вип. 144, с. 327-331, 2017. [Електронний ресурс]. Доступно: http://nbuv.gov.ua/UJRN/VchdpuP_2017_144_78. Дата звернення: Лип. 21, 2019

[2] Anamaria Călin, "IC and online müsic ēucation", ICT in Musical Field, Vol. 9, nr. 2, pp. 7-13, 2018. [Електронний pecypc]. http://www.tic.edituramediamusica.ro/reviste/2018/2/ICTMF_ISSN_20679408_2018_vol_9_issue_2_pg_no_007-013.pdf. Дата звернення: Лип. 21, 2019

[3] JWV, Castro, OCS, Jimenez, "The Technologies of Learning and Knowledge in teacher Education", Revista Condaro, Vol. 15, nr. 68, pp. 180-186, 2019. [Електронний ресурс]. Доступно: https:/conrado.ucf.edu.cu/index.php/conrado/article/view/1003/1025. Дата звернення: Лип. 21, 2019

[4] Н. Попович, “Інформаційно-творче освітнє середовище як умова професійно-творчої самореалізації фахівця з музичного мистецтва”, Інформаційні технології $і$ засоби навчання, Т. 69, № 1, с. 92-99, 2019. [Електронний ресурс]. Доступно: https://journal.iitta.gov.ua/index.php/itlt/article/view/2369. Дата звернення: Лип. 25, 2019

[5] Л. Гаврілова, В. Федоришин, “Проблема формування професійної компетентності майбутніх учителів музики засобами комп’ютерних технологій у теорії вітчизняної мистецької освіти”, Професіоналізм педагога: теоретичні й методичні аспекти: збірник наукових пращьь, Вип. 5, Ч.1, ДВНЗ “Донбаський державний педагогічний університет”, Слов’янськ, 2017, с. 213-225. [Електроннй ресурс]. Доступно: http://www.irbis-nbuv.gov.ua/cgibin/irbis_nbuv/cgiirbis_64.exe?C21COM=2\&I21DBN=UJRN\&P21DBN=UJRN\&IMAGE_FILE_DOW NLOAD=1\&Image_file_name=PDF/prptma_2017_5(1)_22.pdf. Дата звернення: Лип. 21, 2019

[6] І. Пащенко, “Комп’ютерні технології у системі підготовки майбутніх учителів музичного мистецтва”, Вісник Черкаського університету, №3, с. 100-104, 2017. [Електронний ресурс]. Доступно: http://ped-ejournal.cdu.edu.ua/article/view/1541. Дата звернення: Лип. 21, 2019

[7] О. Шарабайко, Smart Notebook: создание интерактивных электронных образовательных ресурсов: (на примере создания учебных материалов для уроков музыки): практикум для студентов учреждений высшего образования обучаюшихся по специальностям: 1-03 0107 Музыкальное искусство. Ритмика и хореография, 1-03 0108 Музыкальное искусство и мировая художественная культура. Минск, Беларусь: БГПУ им. М. Танка, 2018. [Електронний ресурс]. Доступно: https://library.bntu.by/sharabayko-o-g-smart-notebook. Дата звернення: Лип. 21, 2019

[8] N. Nedelcuț, C. G. Pop, "Educators' Training Programs for Integrating ICT in the Field of Music", ICT in Musical Field, Vol. 10, nr. 1, pp. 15-24, 2019. [Електронний ресурс]. Доступно: http://www.tic.edituramediamusica.ro/reviste/2019/1/ICTMF_ISSN_20679408_2019_vol_10_issue_1_pg_no_015-024.pdf. Дата звернення: Лип. 21, 2019

[9] A. Murillo-Ribes, M. Riaño-Galán, N. Berbel-Gómez, "Perception of the use of "Soundcool” as a proposal for intervention in the creation of sound and in the development of teaching competences. An exploratory 
study on pre-service teacher education", Psychology, Society, \& Education, Vol. 10(1), pp. 127-146, 2018. [Електронний ресурс]. Доступно: http://dx.doi.org/10.25115/psye.v10i1.1051. Дата звернення: Лип. 23, 2019

[10] E. Candel, "The use of the game and the cooperative Methodology in Higher Educatio: an alternative for creative teaching", ARTSEDUCA, Num. 23, pp.71-97. [Електронний ресурс]. Доступно: http://dx.doi.org/10.6035/Artseduca.2019.23.4. Дата звернення: Лип. 21, 2019

[11] J. Julia, T. Supriyadi \& P. D. Iswara, "The development of angklung composition teaching materials using Music Notation Software with virtual studio technology integration", International Conference on Mathematics and Science Education (ICMScE 2018), IOP Conf. Series: Journal of Physics: Conf. Series, 1157, 2019. [Електронний ресурс]. Доступно: https://iopscience.iop.org/article/10.1088/17426596/1157/4/042005/pdf. Дата звернення: Лип. 23, 2019

[12] R. Crawford, "Rethinking teaching and learning pedagogy for education in the twenty-first century: blended learning in music education", Music Education Research, Vol. 19, Issue 2, pp. 195-213, 2017. [Електронний ресурс]. Доступно: https://doi.org/10.1080/14613808.2016.1202223. Дата звернення: Лип. 23, 2019

[13] ANNEX key competences for lifelong learning a european reference framework (Brussels, 17.1.2018 COM(2018). ANNEX to the Proposal for a Council Recommendation on Key Competences for Lifelong Learning [Електронний pecypc]. Доступно: https://ec.europa.eu/transparency/regdoc/rep/1/2018/EN/COM-2018-24-F1-EN-ANNEX-1-PART-1.PDF. Дата звернення: Лип. 21, 2019

[14] Верховна Рада України. (2145-VIII від 05.09.2017). Закон Украӥни “Про освіту”. [Електронний pecypc]. Доступно: https://zakon.rada.gov.ua/laws/show/2145-19. Дата звернення: Лип. 19, 2019

[15] А. Хуторской, “Ключевые компетенции: технология конструирования”, Народное образование, № 5, c. 55-61, 2003

[16] В. Калінін, “Формування професійної компетентності майбутнього вчителя іноземної мови засобами діалогу культур”, автореф. дис. канд. наук, Житомир. держ. ун-т, Житомир, 2005

[17] М. Головань, "Компетенція та компетентність: порівняльний аналіз понять”, Педагогічні науки: теорія, історія, інноваційні технологї, № 8, с. 224-233, 2011

[18] Н. Ашихміна, “Сутність і компонентна структура фахової культури майбутніх учителів музики”, Наука і освіта, №1, с. 42-47, 2016. [Електронний ресурс]. Доступно: https://doi.org/10.24195/24144665-2016-1-10. Дата звернення: Лип. 23, 2019

[19] Н. Філіппенко, “Інформаційно-комунікаційні технології навчання музичного мистецтва: досвід Польщі”, Порівняльно-педагогічні студіï, № 2, с. 22-27, 2012. [Електронний ресурс]. Доступно: https://library.udpu.edu.ua/library_files/poriv_ped_stydii/2012/2012_2_3.pdf. Дата звернення: Лип. 30, 2019

[20] О. Листопад, “Інноваційний розвиток освіти й освітні інновації. Понятійно-термінологічний аналіз проблеми”, Інновації у професійно-педагогічній підготовці майбутнього вчителя: методологічні, змістові та методичні аспекти, А. Сбруєва, Ред. Суми, Україна: МакДен, 2011. с. 43-60

[21] Т. Зінська, “Інформаційно-комунікативні технології у сучасній музичній освіті”, Міжн. наук.практ. конф. Професійна мистецька освіта і художня культура: виклики ХХІ століття, Київ, 2014, c. 456-460. [Електронний ресурс]. Доступно: http://elibrary.kubg.edu.ua/id/eprint/5298/1/T_Zinska_16_10_14_konf_IM.pdf. Дата звернення: Лип. 23, 2019

Матеріал надійшов до редакиії 06.08.2019 p.

\title{
ИСПОЛЬЗОВАНИЕ СРЕДСТВ ИКТ ДЛЯ ФОРМИРОВАНИЯ ПРОФЕССИОНАЛЬНОЙ КОМПЕТЕНТНОСТИ БУДУЩИХ УЧИТЕЛЕЙ МУЗЫКАЛЬНОГО ИСКУССТВА
}

\author{
Ашихмина Наталья Витальевна \\ кандидат педагогических наук, старший преподаватель кафедры дирижёрско-хоровой подготовки \\ Государственное учреждение "Южноукраинский национальный педагогический университет \\ имени К. Д. Ушинского”, г. Одесса, Украина \\ ORCID ID 0000-0001-8843-5217 \\ ashihmina_n-81@ukr.net
}




\begin{abstract}
Аннотация. В статье проанализировано значение информационно-коммуникационных технологий для формирования основных компонентов профессиональной компетентности соискателей высшего образования музыкальных факультетов педагогических университетов. Определена сущность профессиональной компетентности будущих учителей музыкального искусства. По мнению автора, данное понятие - интегративное качество, которое является характеристикой приобретенных профессиональных знаний, умений, навыков, сформированных личностных качеств в процессе профессиональной подготовки в пределах музыкально-педагогического вуза для качественного выполнения профессиональной деятельности. Структура исследуемого феномена состоит из следующих компонентов: мотивационно-ценностного, профессионально-когнитивного, профессионально-деятельностного и рефлексивно-творческого. Сделан вывод о том, что формирование профессиональной компетентности будущего учителя музыкального искусства является целенаправленным, непрерывным и поэтапным процессом личностного прогрессивного преобразования и совершенствования в соответствии с требованиями профессиональной музыкально-педагогической деятельности. Автором предложены возможные организационные действия для успешного формирования исследуемого феномена в пределах художественно-педагогического вуза. В качестве эффективных способов формирования основных компонентов профессиональной компетентности будущих учителей музыкального искусства рассмотрены определенные средства ИКТ. Сделаны следующие предположения: формированию мотивационно-ценностного компонента будет способствовать привлечение соискателей высшего образования к созданию мультимедийных самопрезентаций и цифровых портфолио в программах PowerPoint и Authorware; формированию профессионально-когнитивного компонента проектирование электронного учебника (или его фрагмента) в таких программах: E-Book Maestro, Help and Manual E-Book; формированию профессионально-деятельностного компонента - использование нотных редакторов (Finale, Sibelius, Encore); формированию рефлексивно-творческого компонента - применение звуковых редакторов (Sound Forge, Sternberg WaveLab) и музыкальных конструкторов (SunVox, NanoStudio, MadTracker, MuLab).
\end{abstract}

Ключевые слова: профессиональная компетентность; компонентная структура профессиональной компетентности; информационно-коммуникационные технологии; будущий учитель музыкального искусства.

\title{
USE OF ICT TOOLS FOR FORMING THE PROFESSIONAL COMPETENCE OF PROSPECTIVE MUSICAL ART TEACHERS
}

\author{
Nataliia V. Ashykhmina \\ $\mathrm{PhD}$ of Pedagogical Sciences, \\ Senior Lecturer at the Department of Conductor and Choral Training \\ State institution "South Ukrainian National Pedagogical University named after K. D. Ushynsky", \\ Odesa, Ukraine \\ ORCID ID 0000-0001-8843-5217 \\ ashihmina_n-81@ukr.net
}

\begin{abstract}
The article contains the analysis of the significance of the information and communication technologies for the formation of basic components of professional competence of future artistic and pedagogical specialists. The essence of professional competence of prospective musical art teachers is determined. According to the author, that this concept - an integrative quality, which is a characteristic acquired special knowledge, skills, formed personal qualities during the professional training within the musical and pedagogical university for the quality performance of professional activities. The investigated phenomenon consists of motivational and value, professional and cognitive, professional and activity, reflexive and creative components. It is concluded that the formation of professional competence is a goal-oriented continuous phaseby-step process of personal progressive transformation and improvement according to the requirements of professional music and pedagogical activity. The author suggested possible organizational actions for the successful formation of the investigated phenomenon at the artistic and pedagogical university. The article deals with some effective means of information and
\end{abstract}


communication technologies for the formation of basic components of professional competence of prospective teachers of musical art. The author made such assumptions: attracting students to create multimedia self-presentations and digital portfolios in PowerPoint and Authorware programs will contribute to the formation of motivational and value component; designing electronic textbook (or fragment thereof) in the E-Book Maestro, Help and Manual programs will positively influence for the formation of professional and cognitive component; it is advisable to use music editors (Finale, Sibelius, Encore) for the formation professional and activity component; using audio editors (Sound Forge, Sternberg WaveLab), and musical constructors (SunVox, NanoStudio, MadTracker, MuLab) help in the formation of reflexive and creative component.

Keywords: professional competence; structure of professional competence; information and communication technologies; prospective musical art teacher.

\section{REFERENCES (TRANSLATED AND TRANSLITERATED)}

[1] I. Yutsevich, "The problem of readiness of future foreign language teachers to use information technology in the process of special training ", Visnyk Chernigivskogo natsionalnogo pedagogichnogo universytetu, Vol. 144, pp. 327-331, 2017. [Online]. Available: http://nbuv.gov.ua/UJRN/VchdpuP_2017_144_78. Accessed on: July 21, 2019. (in Ukrainian)

[2] A. Călin, "IC and online music education", ICT in Musical Field, Vol. 9, nr. 2, pp. 7-13, 2018. [Online]. Available: http://www.tic.edituramediamusica.ro/reviste/2018/2/ICTMF_ISSN_20679408_2018_vol_9_issue_2_pg_no_007-013.pdf. Accessed on: July 21, 2019. (in English)

[3] JWV, Castro, OCS, Jimenez, "The Technologies of Learning and Knowledge in teacher Education", Revista Condaro, Vol. 15, nr. 68, pp. 180-186, 2019. [Online]. Available: https://conrado.ucf.edu.cu/index.php/conrado/article/view/1003/1025. Accessed on: July 21, 2019. (in Spanish)

[4] N. Popovych, "Information and creative education environment as the condition for the professional and creative self-realization of specialist in musical art", Information Technologies and Learning Tools, Vol. 69, № 1, pp. 92-99, 2019. $\quad$ [Online]. https://journal.iitta.gov.ua/index.php/itlt/article/view/2369. Accessed on: July 25, 2019. (in Ukrainian)

[5] L. Gavrilova, V. Fedoryshyn, "The problem of formation of professional competence of future music teachers by means of computer technologies in the theory of art education ", Teachers professionalism: theoretical and methodological aspects: a collection of scientific papers, Vol. 5, Part 1, Donbas State Pedagogical University, Sloviansk, 2017, pp. 213-225. [Online]. Available: http://www.irbisnbuv.gov.ua/cgi-

bin/irbis_nbuv/cgiirbis_64.exe?C21COM=2\&I21DBN=UJRN\&P21DBN=UJRN\&IMAGE_FILE_DOW NLOAD=1\&Image_file_name=PDF/prptma_2017_5(1)_22.pdf. Accessed on: July 21, 2019. (in Ukrainian)

[6] I. Pashchenko, "Computer technology in the system of training future music teachers", Visnyk Chercaskogo universytetu, №3, pp. 100-104, 2017. [Online]. Available: http://pedejournal.cdu.edu.ua/article/view/1541. Accessed on: July 21, 2019. (in Ukrainian)

[7]O. Sharabaiko, Smart Notebook: creation of interactive electronic educational resources (through the creation of educational materials for music lessons): a practice lessons for students of higher educational institutions enrolled in the specialties: 1-03 0107 Musical Art. Rhythm and choreography, 1-03 0108 Musical art and world artistic culture. Minsk, Belarus, 2018. [Online]. Available: https://library.bntu.by/sharabayko-o-g-smart-notebook. Accessed on: July 21, 2019. (in Russian)

[8] N. Nedelcuţ, C. G. Pop, "Educators' Training Programs for Integrating ICT in the Field of Music", ICT in Musical Field, Vol. 10, nr. 1, pp. 15-24, 2019. [Online]. Available: http://www.tic.edituramediamusica.ro/reviste/2019/1/ICTMF_ISSN_20679408_2019_vol_10_issue_1_pg_no_015-024.pdf. Accessed on: July 21, 2019. (in English)

[9] A. Murillo-Ribes, M. Riaño-Galán, N. Berbel-Gómez, "Perception of the use of "Soundcool" as a proposal for intervention in the creation of sound and in the development of teaching competences. An exploratory study on pre-service teacher education", Psychology, Society, \& Education, Vol. 10(1), pp. 127-146, 2018. [Online]. Available: http://dx.doi.org/10.25115/psye.v10i1.1051. Accessed on: July 23, 2019. (in Spanish)

[10] E. Candel, "The use of the game and the cooperative Methodology in Higher Educatio: an alternative for creative teaching", ARTSEDUCA, Num. 23, pp. 71-97. [Online]. Available: http://dx.doi.org/10.6035/Artseduca.2019.23.4. Accessed on: July 21, 2019. (in Spanish) 
[11] J. Julia, T. Supriyadi \& P. D. Iswara, "The development of angklung composition teaching materials using Music Notation Software with virtual studio technology integration", International Conference on Mathematics and Science Education (ICMScE 2018), IOP Conf. Series: Journal of Physics: Conf. Series, 1157, 2019. [Online]. Available: https://iopscience.iop.org/article/10.1088/17426596/1157/4/042005/pdf. Accessed on: July 23, 2019. (in English)

[12] R. Crawford, "Rethinking teaching and learning pedagogy for education in the twenty-first century: blended learning in music education", Music Education Research, Vol. 19, Issue 2, pp. 195-213, 2017. [Online]. Available: https://doi.org/10.1080/14613808.2016.1202223. Accessed on: July 23, 2019. (in English)

[13] ANNEX key competences for lifelong learning a european reference framework (Brussels, 17.1.2018 COM(2018). ANNEX to the Proposal for a Council Recommendation on Key Competences for Lifelong Learning [Online]. Available: https://ec.europa.eu/transparency/regdoc/rep/1/2018/EN/COM-2018-24F1-EN-ANNEX-1-PART-1.PDF. Accessed on: July 21, 2019. (in English)

[14] Verkhovna Rada of Ukraine. (2145-VIII dated 05.09.2017). Law of Ukraine «On Education». [Online]. Available: https://zakon.rada.gov.ua/laws/show/2145-19. Accessed on: July 19, 2019. (in Ukrainian)

[15] A. Khutorskoi, "Key competencies: design technology”, Narodnoie obrazovaniie, № 5, pp. 55-61, 2003. (in Russian)

[16] V. Kalinin, "The formation of professional competence of the future teacher of a foreign language by means of dialogue of cultures", extended abstract of candidate's thesis, ZhDU, Zhytomyr, 2005. (in Ukrainian)

[17] M. Holovan, "Competency and competence: a comparative analysis of concepts", Pedagogical sciences: theory, history, innovative technologies, № 8, pp. 224-233, 2011. (in Ukrainian)

[18] N. Ashikhmina, "Essence and component structure of future music teachers' specialty culture", Science and Education, №1, pp. 42-47, 2016. [Online]. Available: https://doi.org/10.24195/2414-4665-2016-1-10. Accessed on: July 23, 2019. (in Ukrainian)

[19] N. Filipenko, "Information and communication technologies of musical art teaching: polish experience", Porivnialno-pedahohichni studii, № 2, pp. 22-27, 2012. [Online]. Available: https://library.udpu.edu.ua/library_files/poriv_ped_stydii/2012/2012_2_3.pdf. Accessed on: July 21, 2019. (in Ukrainian)

[20] O. Lystopad, "Innovative development of education and educational innovations. Conceptual and terminological analysis of the problem", Innovations in the future teacher's pedagogical training: methodological, content and methodological aspects, A. Sbruieva, Ed. Sumy, Ukraine: MakDen, 2011. pp. 43-60. (in Ukrainian)

[21] T. Zinska, "Information and communication technologies in modern music education", Internat. scientif. and pract. conf. Professional Art Education and Art Culture: Challenges of the 21st Century, Kyiv, 2014, pp. 456-460. [Online].

Available: http://elibrary.kubg.edu.ua/id/eprint/5298/1/T_Zinska_16_10_14_konf_IM.pdf. Accessed on: July 23, 2019. (in Ukrainian)

\section{(c) EY-NC-SA}

ThisworkislicensedunderCreativeCommonsAttribution-NonCommercial-ShareAlike 4.0 InternationalLicense. 